\title{
PERAN POKDARWIS DALAM UPAYA MENGEMBANGKAN PARIWISATA HALAL DI DESA SETANGGOR
}

\author{
Khairul Amri Assidiq1, Hermanto ${ }^{2}$, Baiq Handayani Rinuastuti ${ }^{3}$ \\ 1 Program Magister Manajemen, Universitas Mataram, Indonesia \\ E-mail: zaerina19@gmail.com \\ 2 Program Magister Manajemen, Universitas Mataram, Indonesia \\ E-mail: hermanto2307@gmail.com \\ 3 Program Magister Manajemen, Universitas Mataram, Indonesia. \\ E-mail: hrinuastuti@yahoo.com
}

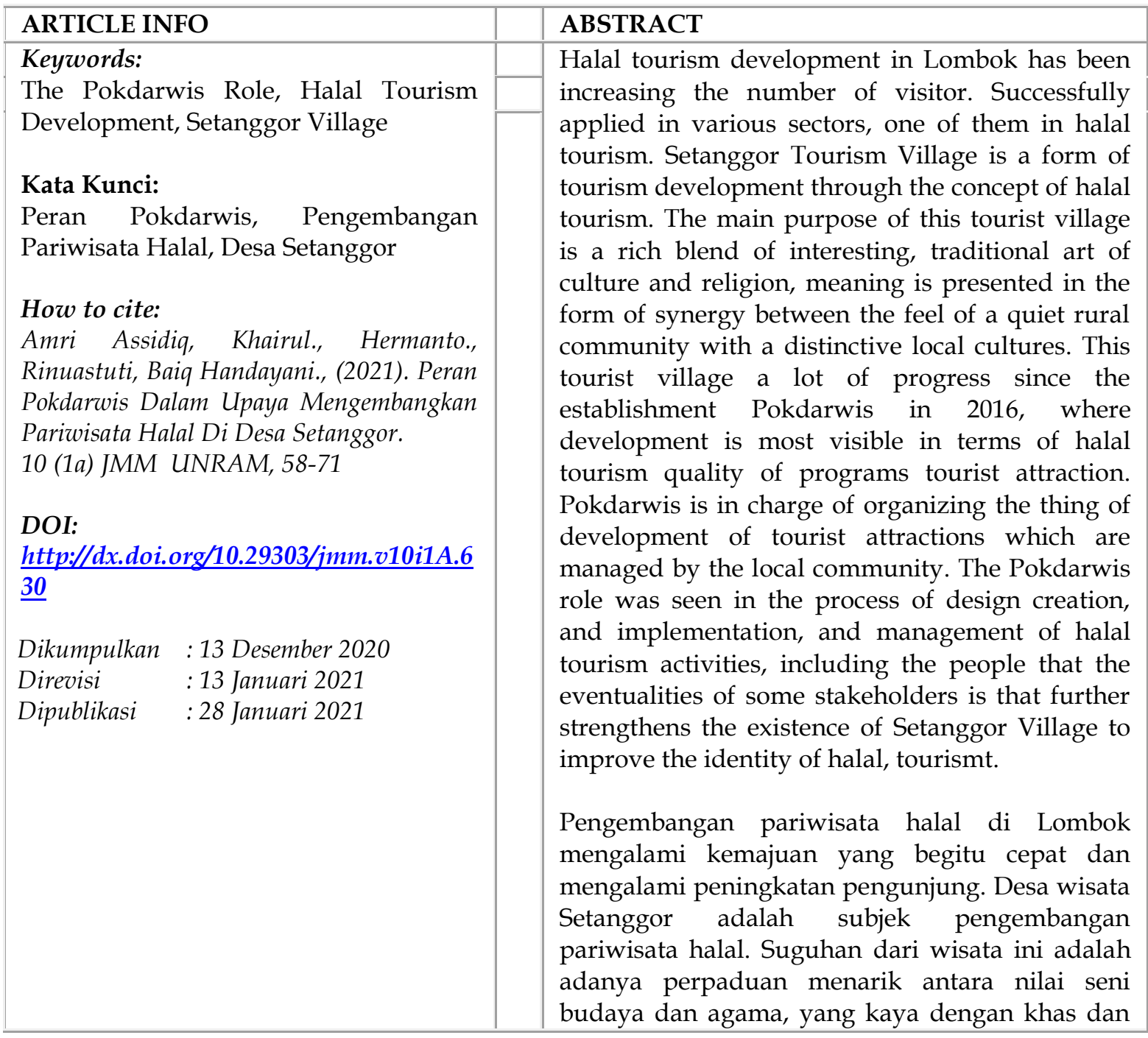




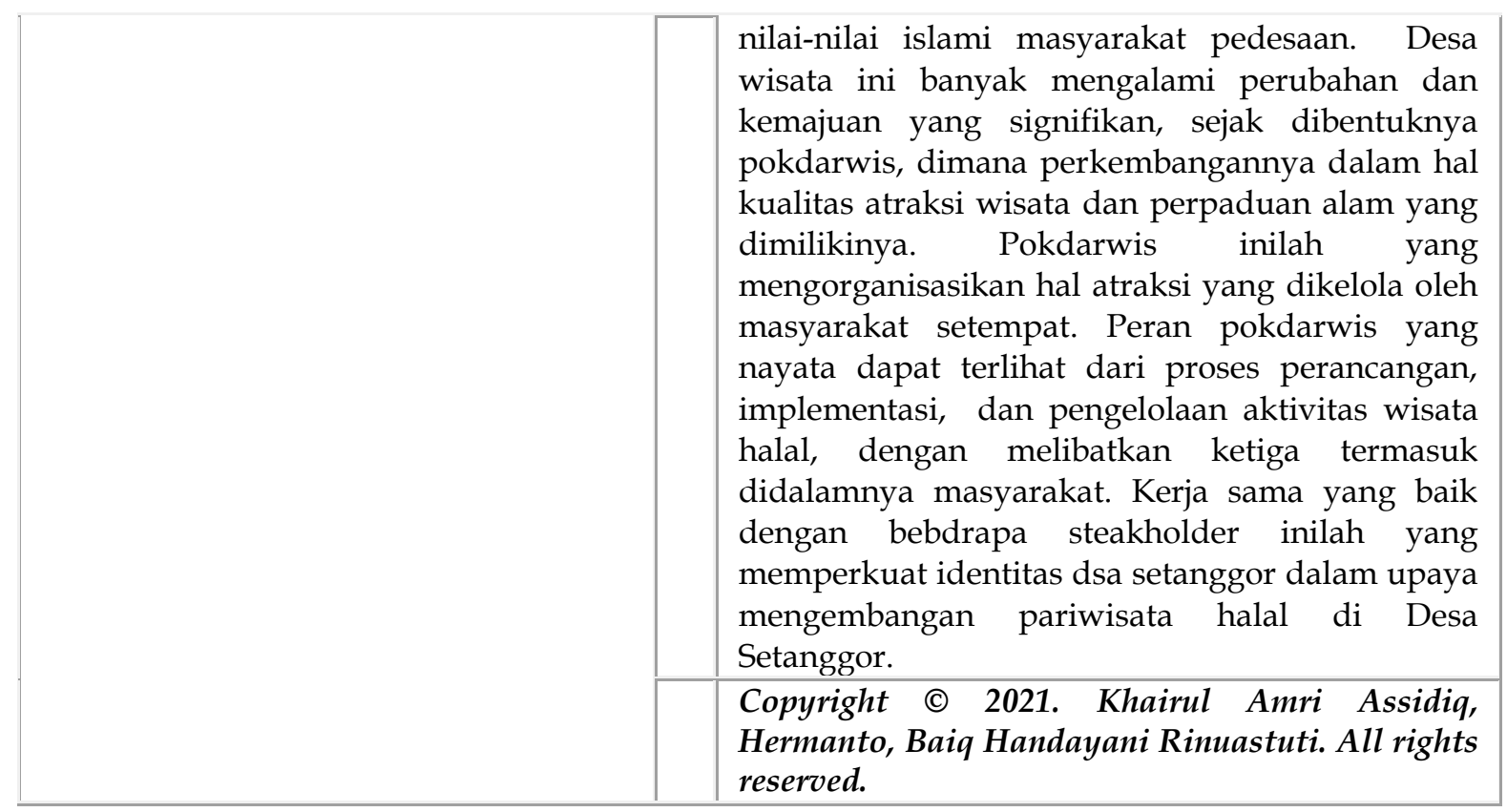

\section{PENDAHULUAN}

Undang-Undang Republik Indonesia Nomor 10 Tahun 2009 tentang Kepariwisataan, menyebutkan bahwa wisata adalah kegiatan perjalanan yang dilakukan oleh seseorang atau sekelompok orang dengan mengunjungi tempat tertentu untuk tujuan rekreasi, pengembangan pribadi, atau mempelajari keunikan daya tarik wisata yang dikunjungi dalam jangka waktu sementara. Usaha pariwisata sebagaimana diatur dalam Undang-Undang RI Nomor 10 Tahun 2009, bab VI, Pasal 14, 2009, mencakup antara lain : daya tarik wisata, kawasan pariwisata, jasa transportasi wisata, jasa perjalanan wisata, jasa makanan dan minuman, penyediaan akomodasi, penyelenggaraan kegiatan hiburan. ( Kemenpar, 2009)

Pariwisata telah berkembang menjadi sebuah industri dengan pertumbuhan yang pesat dan mampu menjadi roda penggerak perekonomian (Pratama, Busaini, dan Saufi, 2020; Sarjan, dkk., 2019; Saufi, dkk., 2015). Pariwisata di Nusa Tenggara Barat menjadi sektor unggulan dalam upaya meningkatkan kesejahteraan masyarakat. Saat ini, pembangunan pariwisata NTB berfokus di pulau Lombok dengan potensi sumberdaya alam dan budaya yang begitu melimpah. Panorama alam mulai dari gunung, perbukitan, perdesaan hingga laut, kultur budaya dan keramah-tamahan masyarakat yang khas menjadi daya tarik tersendiri (Kanom, 2015; Pratama, Busaini, dan Saufi, 2020). Pada tahun 2015 pulau Lombok mendapat pengakuan dunia sebagai World Best Halal Tourism Destination dan World Best Halal Honeymoon Destination dari World Halal Travel Awards (WHTA) (Mastercard Crescent Rating, 2016). Pariwisata Halal berfokus pada keterlibatan (Muslim), tempat (tujuan Islami/Mayoritas penduduk Muslim), produk (daerah tempat tinggal, makanan, dan minuman), dimensi (ekonomi, budaya, lingkungan), dan pengelolaan proses pelayanan (pemasaran dan isu-isu etis). Motivasi dan niat yang sangat penting dalam Islam, karena terkait dengan sikap dan tujuan dalam melakukan perjalanan wisata (Ala-Hamarneh, 2011; Hassan, 2007; Henderson, 2010; Jafari \& Scott, 2014).

Munculnuya konsep pariwisata Halal sebagai langkah baru untuk meningkatkan kepekaan dalam cara dan etika berwisata. Pariwisata Halal sebagai langkah dan aktivitas yang akan menghantarkan kepada kemaslahatan bersama (pelaku industri pariwisata, 
wisatawan dan masyarakat tuan rumah) dan menjadi bagian dari industri ekonomi Islam global (Samori, Salleh, dan Khalid, 2016).

Pratama, Busaini, dan Saufi (2020) menyebutkan bahwa pegiat pariwisata dan masyarakat Lombok telah menyadari pariwisata Halal sebagai potensi besar yang menunjang keberlanjutan industri pariwisata di pulau Lombok. Kesadaran pegiat pariwisata dan masyarakat ini selaras dengan kebijakan pemerintah daerah dalam mengoptimalkan pembangunan pariwisata Halal di NTB. Dengan demikian karakteristik pulau Lombok sebagai pulau seribu masjid semakin menguat (Pratama, Busaini, dan Saufi, 2020; Saufi, dkk., 2015). Selain itu, Adinugraha, Sartika, dan Kadarningsih (2018) turut menyatakan bahwa Desa Wisata sebagai perwujudan dari nuansa religius dan pengejawantahan kehidupan sosial budaya dan sosial ekonomi yang berlandaskan pada syariah. Konsep ini begitu dekat dan mudah diterima oleh seluruh lapisan masyarakat terutama masyarakat di desa, sehingga terdorong untuk dapat terlibat dan terus menjaga kelangsungan usaha pariwisata di pulau Lombok.

Desa Setanggor, Lombok Tengah merupakan salah satu desa yang telah dikembangkan sebagai desa wisata Halal. Desa Setanggor dengan penduduk mayoritas Muslim memiliki kekayaan sumber daya alam yang sangat indah berupa kawasan persawahan yang terbentang luas dan indah, serta memiliki kekayaan warisan budaya seperti membaca daun lontar, hikayat, nembang, gamelan tua, hingga peninggalan gong tua yang sudah berumur ratusan tahun (Suparman, dkk., 2020; Utami, 2020). Utami (2020) juga menyebutkan bahwa pengembangan pariwisata Halal di Desa Setanggor bersumber dari modal sosial masyarakat setempat yang begitu kuat, meliputi kepercayaan sosial, jaringan sosial, dan norma masyarakat untuk tetap saling bekerjasama. Modal sosial ini terkakomodir pula dalam seluruh kelompok masyarakat meliputi aparatur desa, kelompok masyarakat, kelompok perempuan, kelompok pemuda hingga kelompok sadar wisata. Daher (2019) menyebutkan dalam pengembangan desa wisata tidak terlepas dari peran para agen perubahan. Selanjutnya, Karim, Kusuma dan Amalia (2017) mengungkapkan kelompok sadar wisata menjadi agen perubahan dalam mendukung keberlangsungan kepariwisataan. Hal ini selaras dengan pengertian kelompok sadar wisata yang merupakan kelembagaan di tingkat masyarakat yang memiliki kepedulian dan tanggung jawab serta berperan aktif sebagai penggerak dalam mendukung terciptanya iklim kondusif bagi tumbuh dan berkembangnya sapta pesona dalam meningkatkan pembangunan daerah melalui kepariwisataan dan manfaatnya bagi kesejahteraan masyrakat (Kemenparekraf, 2012).

Lombok yang berada di wilayah Nusa Tenggara Barat - diantara destinasidestinasi yang ada di Indonesia, ikut berpartisipasi dalam World Halal Travel Summit yang diselenggarakan di Abu Dhabi selama dua tahun berturut-turut (2015-2016), Lombok meraih predikat: destinasi wisata halal terbaik dunia, pariwisata halal honeymoon terbaik dunia, serta laman wisata halal terbaik (CrescentRating, 2016). Di dalam negeri, Lombok juga terpilih sebagai destinasi wisata halal terbaik di Indonesia mengungguli daerah lainnya (Kemenparekraf, 2019).

Pemerintah daerah sedang gencar-gencarnya mengembangkan pariwisata halal, dengan diterbitkannya Peraturan Gubernur Nomor 51 Tahun 2015 tentang Wisata Halal, dan selanjutnya ditindaklanjuti dengan keluarnya Peraturan Daerah Nomor 2 Tahun 2016, tentang Pariwisata Halal. Guna mendukung pengembangkan pariwisata halal di Lombok, Pemerintah Daerah Provinsi NTB membentuk 99 desa wisata di Lombok-Sumbawa (ntbprov.go.id, 2019), dengan cara mengembangkan pariwisata yang mengutamakan budaya serta nilai-nilai agama (Jaelani, 2017). 
Salah satu desa wisata yang menjadi pilot project di pulau Lombok adalah Desa Setanggor. Desa ini merupakan desa wisata yang menawarkan keunikan dan kelokalan yang terdapat di masyarakat setempat sebagai daya tarik wisata, seperti gamelan, seni tari, drama tradisional, kebiasaan dan ritual religius sebagai implikasi dari kehidupan masyarakat suku Sasak (Sukmayeti \& Utami, 2018; Utami, 2020) ditambah dengan suguhan makanan minuman tradisional, kekayaan alam, kerajinan tenun berbahan alam, kehidupan sehari-hari, dan atraksi wisata yang dipadukan dengan nilai-nilai Islam seperti wisata ngaji di tengah sawah.

Pemanfaatan semua potensi yang dikemas menjadi produk wisata mampu melestarikan kearifan lokal masyarakat dan lingkungan. Menurut Ida Wahyuni (dalam Utami, 2020) salah satu cara yang dapat mengintegrasikan seluruh potensi yang ada yakni menjadikan Desa Setanggor sebagai desa wisata halal, yang setiap pengembangannya tidak merusak nilai-nilai yang dipercayai oleh masyarakat dan kualitas lingkungan tidak mengalami penurunan atau rusak, serta dapat memaksimalkan keuntungan ekonomi untuk masyarakat lokal. Langkah lainnya yang berdampak besar bagi percepatan lompatan pengembangan pariwisata halal di Desa Setanggor ialah dibentuknya Pokdarwis Sekar Tije Mertakmi yang beranggotakan seluruh kepala dusun (Utami, 2020), dan melibatkan sebagian dari pemuda yang memiliki kepedulian dan bertanggung jawab serta berperan dalam mengembangkan kepariwisataan di desanya.

Akan tetapi dalam pengembangan pariwisata Halal, belum terlihat adanya kerjasama dan kebersamaan hubungan sosial pemuda dengan orang dewasa yang berdampak pada kesiapan pada sumber daya manusia dalam mengembangkan pariwisata halal belum memadai. Ditambah lagi dengan rendahnya partisipasi pemuda pada awal perencanaan dan pengambilan keputusan untuk mengembangkan pariwisata, pemuda lebih memilih mencari penghasilan diluar daerahnya karena kondisi ekonomi daripada membangun wisata dilingkungannya. Padahal sumber daya manusia adalah aktor penting dalam industri pariwisata yang memiliki keterkaitan baik secara langsung maupun tidak langsung dengan komponen pariwisata (Pajriah, 2018). Maka dari itu, perhatian terhadap kualitas sumber daya manusia sangatlah penting dalam menentukan keberhasilan pengembangan pariwisata khususnya pariwisata halal di desa setanggor.

Berdasarkan ulasan diatas menunjukkan bahwa pengembangan desa wisata Setanggor sebagai desa wisata Halal tidak terlepas dari potensi kultur budaya yang sangat erat dengan nilai Islami (Adinugraha, Sartika, dan Kadarningsih, 2018 dan Utami, 2020). Artinya masyarakat desa Setanggor telah sadar akan potensi pariwisata dan turut terlibat mengembangkan pariwisata dengan modal sosial yang dimiliki dalam menciptakan kawasan pariwisata yang kondusif (Dahen, 2019). Akan tetapi, pengembangan desa wisata Halal di desa Setanggor belum ditemukan penelitian yang secara khusus membahas peran kelompok sadar wisata. Padahan, hasil penelitian Karim, Kusuma dan Amalia (2017) di Kota Balikpapan menyebutkan bahwa kelompok sadar wisata memiliki andil besar dalam pengembangan dan keberlangsungan kepariwisataan. Untuk itu perlu dilakukan penyelidikan keterlibatan dan peranan kelompok sadar wisata dalam mengembangkan konsep pariwisata Halal di Desa Setanggor.

\section{KAJIAN PUSTAKA}

\subsection{Kelompok Sadar Wisata ( Pokdarwis)}

Pokdarwis merupakan salah satu bentuk kelembagaan yang dibentuk oleh masyarakat yang memiliki kepedulian dan tanggung jawab serta berperan dalam mendukung terciptanya iklim kondusif dan terwujudnya Sapta Pesona (aman, tertib, 
bersih, sejuk, indah, ramah dan unsur kenangan) sehingga dapat mendorong dalam mengembangkan dan membangun kepariwisataan di suatu daerah dan bermanfaat bagi kesejahteraan masyarakat sekitar (firmansyah rahim, 2012). Adanya pokdarwis dibentuk oleh dinas pariwisata berdasarkan peraturan menteri kebudayaan dan pariwisata No PM04/UM.001/MKP/108 tentang sadar wisata. Pokdarwis dibentuk oleh dinas pariwisata berdasarkan peraturan menteri kebudayaan dan pariwisata no PM04/UM.001/MKP/08 tentang sadar wisata. Pokdarwis merupakan salah satu bentuk program dari banyak program pengembangan destinasi pariwisata yang dibuat oleh pemerintah pusat dan daerah untuk memajukan pariwisata sekaligus mengembangkan ekonomi rakyat.

Pembentrukan Pokdarwis didasarkan pada instruksi Presiden Republik Indonesia Nomor 16 tahun 2005 Tentang kebijakan Pembangunan Kebudayaan dan Pariwisata. Kedudukan Pokdarwis sebagai Organisasi dibawah Departemen Kebudayaan dan Pariwisata seperti disebutkan dalam peraturan Menteri kebudayaan dan Pariwisata Nomor PM.07/HK.001/MKP-2007 Tentang perubahan kedua atas peraturan Menteri Kebudayaan dan pariwisata Nomor PM.17/HK.001/MKP-2005 tentang Organisasi dan tata kerja Departemen Kebudayaan dan Pariwisata. Tujuan dari pembentukan kelompok sadar wisata (Pokdarwis) ini sebagai berikut :

1. Meningkatkan posisi dan peran masyarakat sebagai subjek atau pelaku penting dalam pembangunan kepariwisataan serta dapat bersinergi dan bermitra dengan pemangku kepentingan terkait dalam meningkatkan kualitas kepariwisataan di daerah.

2. Membangun dan menumbunkan sikap dan dukungan positif masyarakat, sebagai tuan rumah melalui perwujudan nilai-nilai sapta pesona bagi tumbuh dan berkembangnya kepariwisataan daerah dan manfaatnya baginpembnagunan daerah maupun kesejahteraan masyarakat.

3. Memperkenalkan melestarikan dan memanfaatkan potensi daya tarik wisata yang ada di masing-masing daerah.

1. Daerah tersebut harus mempunyai something to see, artinya ditempat tersebut harus memiliki objek wisata yang berbeda dengan apa yang dimiliki oleh daerah lain.

2. Di Daerah tersebut harus tersedia something to do, artinya yaitu ditempat tersebut banyak yang dapat dilihat serta disaksikan,serta disaksikan,dan harus disediakan tempat rekreasi yang dapat membuat mereka tinggal lebih lama ditempat itu.

3. Di daerah tersebut harus tersedia something to buy, artinya ditempat tersebut harus tersedia fasilitas perbelanjaan atau shopping, terutama barang-barang souvenir dan kerajinan rakyat sebagai oleh-oleh yang dibawa pulang ke tempat asal masingmasing (Oka A Yoeti,1996: 177-178)

Menurut I Gde Pitana dan Putu G. Gayatri (2005: 96-97) menyatakan bahwa dibutuhkan kerjasama antara para stakeholders untuk menggerakan pariwisata. Para stakeholders tersebut adalah insan-insan pariwisata yang ada pada berbagai sektor. Secara umum insan pariwisata dikelompokkan dalam tiga pilar utama yaitu masyarakat, swasta, dan pemerintah. Kelompok masyarakat ini meliputi tokoh-tokoh masyarakat, intelektual, LSM, dan media masa. Kelompok swasta meliputi asosiasi usaha pariwisata dan para pengusaha, sedangkan kelompok pemerintah meliputi pada berbagai wilayah administasi, mulai dari Pemerintah Pusat, Provinsi, Kabupaten, Kecamatan, dan seterusnya.

\subsection{Pariwisata Halal}

Pariwisata Halal menjadi pusat perhatian dari pelaku industri, akademisi hingga stakeholder pariwisata lainnya diberbagai negara (Jafari dan Scott, 2014; Batour dan Ismail, 2015; dan Duman, 2012). Pengembangan konsep pariwisata Halal memiliki tantangan tersendiri karena harus menyelaraskan atau mendekati konsep yang berkaitan antara 
pariwisata dan hubungannya dengan agama Islam dan konsumsi Islami (Duman, 2012). Sehingga definisi tentang pariwisata Halal masih ambigu, karena hanya menyiratkan pada layanan akomodasi yang sesuai dengan ketentuan nilai-nilai Islam (Duman, 2012; dan Gabdrakhmanov, Biktunirov, Rozhko dan Mardanshina, 2016). Kemudian Batour dan Ismail (2015) juga menyebutkan bahwa pariwisata Halal masih dalam tatanan multidisiplin ilmu sehingga banyak bermunculan terminologi dan difinisi tersendiri. Saat ini, populasi dunia mengalami peningkatan yang besar terutama populasi Muslim. Pertumbuhan populasi Muslim mencapai 26 persen dari populasi dunia dan kemajuan teknologi saat ini memberikan pengaruh besar pada persaingan di industri pariwisata dunia (GMTI, 2012; 2015; Duman, 2012). Diperkirakan kunjungan wisatawan Muslim akan mengalamai peningkatan 10 persen setara dengan 156 juta wisatawan Muslim yang melakukan perjalanan di tahun 2020 dan akan mencapai 230 juta di tahun 2026 (GMTI, 2018 dan 2019). Adanya perubahan perilaku dan peningkatan daya beli dari konsumen Muslim mengindikasikan pada meningkatnya permintaan produk-produk sesuai kebutuhan Muslim (GMTI, 2012; Jafari dan Scott, 2014; Gabdrakhmanov, Biktunirov, Rozhko dan Mardanshina, 2016; Husen dan Zhafira, 2019), dan meningkatkan ketersediaan produk Halal (supply-deman). Fenomena ini mendorong munculnya konsep pariwisata halal sebagai produk unggulan di sektor pariwisata yang menjadikan muslim sebagai segmentasi pasar baru yang sangat menjanjikan (Duman, 2012; Batour dan Ismail, 2015; Subarkah, 2018; dan KNKS, 2019).

Pariwisata halal merupakan sebuah konsep baru dalam dunia pariwisata yang memadukan nilai-nilai agama Islam dalam kegiatan pariwisata, dengan menyediakan produk dan layanan yang dibutuhkan oleh wisatawan Muslim tanpa mendiskriminasikan wisatawan non-Muslim. Ditambah lagi, konsep pariwisata halal ini merupakan suatu produk pelengkap dalam model pariwisata modern yang lebih didominasi oleh nilai-nilai Barat yang sangat bertentangan dengan gaya hidup masyarakat Muslim, tanpa menghilangkan jenis pariwisata konvensional (Battour \& Ismail, 2016). Oleh karena itu, kemunculan pariwisata halal sebagai konsep baru dalam berwisata membuatnya terkenal.

Pariwisata Halal adalah segmen pasar yang berkembang pesat tidak hanya di negara-negara Muslim tetapi secara global. Banyak negara termasuk negara-negara Muslim dan negara-negara non-Muslim bersaing untuk menarik wisatawan Muslim dengan memenuhi semua kebutuhan Muslim dalam industri pariwisata (Battour \& Ismail, 2016; Samori, Salleh \& Khalid, 2016).

Maka dari itu, pariwisata Halal ini diatur untuk memudahkan para wisatawan muslim dalam berkegiatan wisata baik di negera muslim maupun negara yang secara populasi penduduk muslimnya sedikit (Battour \& Ismail, 2016; Jafari \& Scott, 2014).

"Pariwisata Halal adalah sama seperti pariwisata pada umumnya hanya menyiapkan Extended Service (layanan tambahan) bagi wisatawan muslim. Secara generik, Pariwisata Halal diantaranya adalah dapat berupa wisata alam, wisata budaya, maupun wisata buatan dalam bingkai wisata keluarga (Halal lifestyle)". (Djakfar, 2017).

Sebaliknya kemunculan produk pariwisata halal di negara-negara yang jumlah penduduk Muslimnya banyak dipengaruhi oleh adanya kekayaan budaya masyarakat lokal yang sesuai dengan ajaran Islam (Zamani-Farahani \& Musa, 2012), kemudian banyaknya situs-situs keagamaan dan budaya yang berkaitan dengan Islam serta adanya ketersediaan makanan halal (Nisthar \& Nufile, 2016; Bastaman, 2018).

Maka pariwisata halal dapat menjadi salah satu motivasi bagi wisatawan nonMuslim yang mencari pengalaman budaya (Battour, Ismail \& Battor, 2010), yakni mencari pengalaman rohani (Tourism Business Portal, 2014 Karena pariwisata halal tidak hanya khusus atau dipromosikan hanya ke pasar Muslim saja (El-Gohary, 2016). Motivasi 
berwisata seperti ini sangat sesuai dengan rangkaian aktivitas social serta penyiapan produk. Dari penjabaran di atas dapat diketahui bahwa, pariwisata halal sebagai upaya dalam rangka menjaga keutuhan dan aktivitas yang selalu menjaga hubungan secara universal serta mendekatkan diri kepada Sang Khaliq.

\subsection{Peran Pokdarwis dalam mengembangkan Pariwisata Halal}

Pokdarwis merupakan salah satu bentuk kelembagaan yang dibentuk oleh masyarakat yang memiliki kepedulian dan tanggung jawab serta berperan dalam mendukung terciptanya iklim kondusif dan terwujudnya Sapta Pesona (aman, tertib, bersih, sejuk, indah, ramah dan unsur kenangan) sehingga dapat mendorong dalam mengembangkan dan membangun kepariwisataan di suatu daerah dan bermanfaat bagi kesejahteraan masyarakat sekitar (firmansyah rahim, 2012). Kelompok Sadar Wisata memiki peran besar atas pengembangan pariwisata halal di Desa setanggor. Pemanfaatan semua potensi yang dikemas menjadi produk wisata mampu melestarikan kearifan lokal masyarakat dan lingkungan. Menurut Ida Wahyuni (dalam Utami, 2020) salah satu cara yang dapat mengintegrasikan seluruh potensi yang ada yakni menjadikan Desa Setanggor sebagai desa wisata halal, yang setiap pengembangannya tidak merusak nilai-nilai yang dipercayai oleh masyarakat dan kualitas lingkungan tidak mengalami penurunan atau rusak, serta dapat memaksimalkan keuntungan ekonomi untuk masyarakat lokal. Langkah lainnya yang berdampak besar bagi percepatan lompatan pengembangan pariwisata halal di Desa Setanggor ialah dibentuknya Pokdarwis Sekar Tije Mertakmi yang beranggotakan seluruh kepala dusun (Utami, 2020), dan melibatkan sebagian dari pemuda yang memiliki kepedulian dan bertanggung jawab serta berperan dalam mengembangkan kepariwisataan di desanya. Desa Setanggor, Lombok Tengah merupakan salah satu desa yang telah dikembangkan sebagai desa wisata Halal. Desa Setanggor dengan penduduk mayoritas Muslim memiliki kekayaan sumber daya alam yang sangat indah berupa kawasan persawahan yang terbentang luas dan indah, serta memiliki kekayaan warisan budaya seperti membaca daun lontar, hikayat, nembang, gamelan tua, hingga peninggalan gong tua yang sudah berumur ratusan tahun (Suparman, dkk., 2020; Utami, 2020). Utami (2020) juga menyebutkan bahwa pengembangan pariwisata Halal di Desa Setanggor bersumber dari modal sosial masyarakat setempat yang begitu kuat, meliputi kepercayaan sosial, jaringan sosial, dan norma masyarakat untuk tetap saling bekerjasama. Adanya Kelompok sadar Wisaata di desa Setanggor sebagi upaya untuk terus mengembangkan konsep parwisata halal. Selain itu, Adinugraha, Sartika, dan Kadarningsih (2018) turut menyatakan bahwa Desa Wisata sebagai perwujudan dari nuansa religius dan pengejawantahan kehidupan sosial budaya dan sosial ekonomi yang berlandaskan pada syariah.

Sesuai yang dikemukakan oleh (Soekanto, 1990) Peran Merupakan aspek dinamis kedudukan (status). Seseorang melaksanakan hak dan kewajibannya sesuai dengan kedudukannya maka dia bisa disebut menjalankan suatu peranan. Peranan yang melekat pada diri seseorang harus dibedakan dengan posisi dalam pergaulan kemasyarakatan, posisi seseorang dalam masyarakat meruan unsur statis yang menunjukan tempat individu pada organisasi masyarakat. Hal serupa peranan mempunyai arti tindakan yang dilakukan seseorang atau sekelompok orang dalam suatu peristiwa atau bagian yang dimainkan seseorang dalam suatu peristiwa. (Kamus Besar Bahasa Indonesia, 2008). Kelompok yang terdiri dari unsur Para orangtua, tokoh adat, tokoh agama dan tokoh pemuda yang tergolong di kelompok sadar wisata Pokdarwis Skartije. Pengembangan potensi sumber daya manusia didalamnya, terus di ikhtiarkan bersama. 


\section{METODOLOGI PENELITIAN}

Penelitian ini menggunakan jenis metode kualitatif (qualitative research). Sebuah penelitian yang akan bertujuan untuk mengetahui fenomena-fenomena yang dialami oleh subyek penelitian seperti; perilaku, persepsi, motivasi, tindakan, dan lain-lain secara holistic pada suatu konteks khusus secara alamiah (Moleong, 2018), yang terjadi pada individu atau kelompok pada suatu permasalahan sosial (Creswell, 2015) guna memandang, memahami serta melihat keadaan masyarakat khususnya pemuda Desa Setanggor. Data dalam penelitian ini berupa kata - kata dan tindakan para informan, foto dan data statistik (Lofland dalam Moleong, 2018). Untuk mendapatkan informasi ditentukan dengan purposive sampling yang merupakan teknik penentuan sampel berdasarkan pertimbangan tertentu, yang dianggap cocok dengan karakteristik sampel yang ditentukan dan dijadikan sampel (Malhotra, 2014). Perolehan data dapat diperoleh melalui observasi dan wawancara mendalam terhadap para pegiat pariwisata meliputi: Kepala Desa, Ketua Pokdarwis dan anggota, Pemuda yang tergabung di dalam struktur Pokdarwis Sekar Tije Mertakmi dan Karang Taruna Desa Setanggor, Penyedia Jasa Pariwisata, dan Tokoh Adat, Agama/Budaya. Data yang diperoleh kemudian dilakukan reduksi data, penyajian data, verifikasi dan penarikan kesimpulan (Miles \& Huberman, 2009).

\section{HASIL DAN PEMBAHASAN}

\subsection{Menjalin Hubungan yang saling menguntungkan}

Apapun bentuk aktivitas kepariwisataan tidak akan mampu bertahan dan berkembang, tanpa adanya jalinan kerja sama yang baik antara semua elemen. Proses pengembangan suatu desa wisata mebutuhkan pengalaman sebelumnya dari pihak lain. Proses yang dilakukakn di desa wisata halal di Desa Setanggor dalam upaya mengembangkan, tidak serta merta cukup dengan potensi masyarakat setempat yang dimiliki. Kekuatan menciptakan dan membangun relasi dengan pihak luar, sangat dibutuhkan untuk bersama-sama dalam rangka terus berikhtiar membangun aktivitas kepariwisataan yang syarat dengan nilai- nilai positive. Jaringan yang kuat akan mampu menciptakan pola dan pengembangan pariwisata secara masiv. Hubungan mampu mengantarkan kedalam semua aspek-aspek kehidupan social, dalam mengembangakan pariwisata halal di desa setanggor. Kesadaran steak holder dan mayarakat di desa setanggor mampu menciptakan dan menjalin hubungan baik dengan berbagai elemen kepariwisataan.

Para pegiat wisata memiliki hubungan kerjasama dengan pihak-pihak luar, yakni menjalin mitra dengan pihak pemerintah setempat dan komunitas-komunitas lainnya, praktisi pariwisata dan pihak para akademis. Hal yang dilakukan tentunya, dalam rangka untuk terus meningkatkan kulitas sumber daya manusia dalam terus berupaya mengembangkan pariwisata halal di Desa Setanggor. Keaktifan steak holder dalam bentuk kerjasama dengan pengelola pariwisata mampu menciptakan keselarasan dan keberlangsungan sistem kepariwisataan sistem yang lebih efektif dan teratur. Dari pihak Akademisi pun turut terjun langsung menjadi bagian dari proses pengembangan pariwisata di Desa Setanggor. Perwujudan para akakademisi tentunya memiliki peranan penting untuk membantu menyumbangkan gagasan, serta ide-ide cemerlang dalam menyelesaikan permasalahan yang di ranah social, dari sisi keilmuan. Kolaborasi dan keterlibatan antara akademisi dan praktisi lapanganakan mampu menjadi dorongan yang kuat dan sebagai pemantik dalam pencapian pembangunan pariwisata halal dan berkelanjutan. 
Sampai saat ini Desa Setanggor mampu membangun kerjasama dengan berbagai elemen, kepariwisataan seperti Travel agent, Perguruan tinggi Universitas Mataram, Sekolah tinggi Pariwisata Mataram,...ASDP, ....ITDC, ....BWS PU dalam program Kuliah Kerja Nyata Kampus Unram memberikan mahasiswanya kesempatan untuk melakukan aktivitas pembelajaran di . Kesemua itu di lakukan untuk memberikan semangat kepada kaum muda dan masyrakat setempat untuk terus berkreasi disini untuk memicu masyarakat dan pemuda disini untuk meningkatkan kapasitas diri, dan skill. (Ma'ruf)

Keseriusan dan komitmen yang kuat menjadi pondasi awal dalam melakukan aktivitas apa saja. Desa Setanggor harus mampu terus melangkah kedepan dalam rangka kemajuan pariwisata halal. Dengan keterlibatan elemen masyrakay akan mempermudah jalannya sistem pariwisata. Konsep musyawarah dan duduk bersama selalu di lakukan dalam menyelesaikan segala jenis kerumitan dan masalah desa. Apapun jenis kesepakatan atau aktivitas yang kan dilakukan harus datas dasar musyawarah. Keselaran kelompok sadar wisata dengan aparatur pemerintah Desa Setanggor telihat dengan adanya anggaran khusus untuk peningkaatan dan kemajuan pariwisata.(Kepala Desa Setanggor)

\subsection{Mempersiapakan generasi masa depan}

Jenis aktivitas sosial kemasyarakatan tentunya menjadi tolak ukur bagaimana Sesungguhnya, menjain dan merajut hubungan baik. Permasalahan yang ada pada pemuda bukanlah hal yang mesti dihindari oleh orang dewasa melainkan mencari tahu apa yang mesti dilakukan untuk memperkuat visi misi bersama, memiliki semangat juang dalam memajukan Desa Setanggor. Salah satu pendekatan yang dilakukan oleh orang dewasa yang tergabung dalam kelompok sadar wisata (skartije) adalah dengan merangkul generasi muda yakni membangun komunikasi yang baik dengan bahasa yang santun. Sehingga pemuda dapat terlibat secara aktif dalam pengembangan pariwisata, adanya kaum muda dalam struktur pokdarwis menjadi salah satu langkah untuk mempersiapkan mimpi besar.ergabung dalam anggota pokdarwis pemuda juga dapat merasakan dampak positif dari aktifitas wisata tersebut. Informan mengatakan "Yang perlu perhatian mungkin dari pendekatan dengan para pemuda (Saleh).

Bahasa yang baik mampu menghadirkan kembali semangat muda untuk ikut berpartisipasi aktif untuk mengembangkan Desa Setanggor. Karena dengan bahasa yang santun dapat menciptakan rasa saling menghargai antara pemuda dan orang dewasa. Sehingga mereka bertindak secara bersama-sama dalam setiap agenda apapun yang ada di Desa Setanggor. Informan mengatakan " Orang tua dan para pemuda saat ini terlihat saling membantu dan bekerjasama khususnya dalam upacara keagamaan acara budaya Alhamdulillah. Dukungan dari pemerintah dan orang tua sangaltlah besar untuk kaum muda, dalam rangka mengembangkan bakat masing " (Sapta)

Pada intinya pembelajaran dari pengalam orangtua dapat di jadikan sebagai acuan untuk melangkah kea rah yang lebih baik.

\subsection{Sosialisasi tentang bisnis Pariwisata Bagi Masyarakat}

Munculnya kelompok sadar wisata di desa setanggor yang tergolong dalam kelompok pokdarwis Skartije, mampu memberikan efek dan pengaruh yang memeberikan nilai yang positif bagi masyarakat lokal, yakni kelompok sadar wisata mensosilisasikan tawaran bisnis pariwisata bagi masyarakat. Adanya kunjungan tamu dari dalam dan luar negeri ke desa Setanggor menjadi salah satu bukti bahwasanya adanya potensi yang besar. Untuk mengawali pengembangan aktifitas pariwisata, penyedian tempat tinggal bagi wisatawan sebagi langkah baru bagi masyrakat sekitar untuk membuka peluang usaha. 
“Adanya minat berbisnis seperti ini, memang dari awal kita masih awam tetapi ada ponakan-ponakan atau anak-anak muda disini yang memberitahu kami tentang adanya tamu yang tertarik dan mau diajak ke Setanggor, awalnya menginep di rumah biasa, lama kelamaan makin banyak yang datang ya kami harus buat homestay juga untuk itu selain dari homestay ada di rumah-rumah warga juga yang lain untuk jadikan Homestay" (Sapri)

Masyarakat Lokal diberikan keyakinan oleh pemuda yang tergabung sebagai anggota kelompok sadar wisata telah memiliki pengalaman bekerja di luar desanya untuk mengajak masyarakat membuat homestay, dan meyakinkan penyedia jasa untuk membangun usaha pariwsata, seperti penginapan sementara (homestay) hal itu dimaksud supaya masyrakat bisa memperoleh keuntungan dari bisnis tersebut. Pengalaman dari kaum muda yang berada di luar desa yang bekerja di industry pariwisata, membuatnya memiliki tanggung jawab besar untuk mengembangkan pariwisata di Desa Setanggor.

"Untuk keberlanjutan usaha kami, Kami masih butuh Pemuda karena mereka banyak tahu tentang situasi pariwisata di luar Desa kami, awalnya juga kan saya diajak oleh pemuda dari desa ini dan kami sangat percaya mereka karena kami melihat bahwa mereka sering bawa tamu, kemudian saya juga terima karena pemuda-pemuda ini keluarga Kami jadi kami ikuti saja sesuai dengan arahan mereka. Jadi kami keluarga pun sangat mendukung kalau itu untuk kebaikan bagi kami keluarganya dan mereka juga" (Khairunnisa)

"...pemuda melihat bahwa prospek untuk makanan juga bagus, malahan mereka ingin buat tempat makan di sini kalau ada rezeki kami bangun bersama sesuai dengan apa yang menjadi ide-ide yang baik dari mereka. Mereka bilang kita bikin di sini karena memang itu adalah pengetahuan yang mereka dapat dari sana, malah kami diajarin oleh mereka yang kerja di Gili Trawangan, di hotel di mana-mana itu, gini cara bikin masakan-masakan begini paman seperti buat pancake, disuguhkannya dengan cara seperti ini dan modelnya seperti ini karena itu adalah kebutuhan mereka begitu kata mereka" (Ketua Pokdarwis)

Inisiatif yang muncul dari kelompok sadar ( skaertije) mendapatkan dukungan dari masyarakat lokal yang sedang mengembangkan suatu bidang bisnis kepariwisataaan di Desa Setanggor. Dukungan dari pemerintah setempat tentunya menjadi ruang gerak untuk terus berinovasi dan berkonstribusi bersama-sama dalam rangka pengembangan pariwisata halal.

\section{KESIMPULAN DAN SARAN}

\subsection{Kesimpulan}

Peran Pokdarwis dalam upaya pengembangan Pariwiata Halal Desa Setanggor ini terbagi menjadi beberapa tahapan, dimana salah satu peran Pokdarwis yang krusial adalah dalam proses pengembangan programprogram atraksi wisata halal. Peran dimksud bukan hanya untuk anggota saja, akan tetapi elemen masyarakat juga mengambil bagian didalamnya. Keberhasilan tiap devisi pokdarwis dipengaruhi oleh masing-masing ketua devisi yang bertugas mengkoordinasikan seluruh kegiatan pengembangan dan pengelolaan atraksi wisata. Kehadiran ketua seksi yang memiliki ide inovasi tentunya dapat menentukan seberapa besar kualitas dan kuantitas atraksi wisata yang mampu dikelolanya. Oleh karena itu, kiranya perlu ada perhatian lebih serius terhadap pengembangan pariwisata halal, sebagai modal penting dalam pembangunan pariwisata halal di desa setanggor. 


\subsection{Saran}

Peran Kelompok Sadar Wisata Sekar Tije perlu menjaga konsistensi masyrakat sekitar untuk tetap melestarikan budaya Sasaq yang tentunya tidak terlepas dari nilainulai islami, dengan memperbanyak kegiatan-kegiatn yang positif. 


\section{DAFTAR PUSTAKA}

Battour, M.M., Ismail, M.N., \& Battor, M. (2010), “Toward a Halal tourism market”, Tourism Analysis, 15 (4), 461-470.

Battour, M.M., Ismail, M.N., \& Battor, M. (2010), "Toward a Halal tourism market", Tourism Analysis, 15 (4), 461-470.

Burt, R.S. (1992), Structural Holes: The Social Structure of Competition, Cambridge: Harvard University Press.

Creswell, J.W. (2015), Penelitian Kualitatif \& Desain Riset, Yogyakarta: Pustaka Pelajar.

Djakfar, M. (2017), Peta Jalan Menuju Pengembangan Akademik E Industri Halal di Indonesia, Malang: UIN-Maliki Press

Dworkin, J., Larson, R., \& Hansen, D. (2003), “Adolescents' accounts of growth experiences in youth activities" Journal of Youth and Adolescence, 32, 17-26.

El-Gohary, H. (2016), "Halal tourism, is it really halal?", Tourism Management Perspectives, $19,124-130$.

Emery, M. (2013), “Social capital and youth development: Toward a typology of program practices", New Directions for Youth Development, 138, 49-59.

Fukuyama, F. (1995), Trust: The social virtues and the creation of prosperity, New York: Free Press.

Grassl, W., \& Habisch, A. (2011), "Ethics and Economics: Towards a New Humanistic Synthesis for Business", Journal of Business Ethics 99 (1): 37-49.

Hardianto, (2017), "Pentingnya Modal Sosial dalam Pengembangan Pariwisata Nasional", Seminar Nasional Sistem Informasi, Fakultas Teknologi Informasi - UNMER Malang, Indonesia.

Helve, H., \& Bynner, J. (2007), "Youth and Social Capital". ResearchGate.

Holland, J., Reynolds, T., \& Weller, S. (2007), "Transitions, networks and communities: The significance of social capital in the lives of children and young people", Journal of Youth Studies, 10 (1), 97-116.

Hwang, D., dan Stewart, W. P. (2016). Social Capital and Collective Action in Rural Tourism.bJournal of Travel Research, Vol. 56(1) 81 -93

Jafari, J., \& Scott, N. (2014), "Muslim world and its tourisms", Annals of Tourism Research, 44, 119.

Jarrett, R.L., Sullivan, P.J., \& Watkins, N.D. (2005), “Developing social capital through participation in organized youth programs: Qualitative insights from three programs", Journal of Community Psychology, 33 (1), 41-55.

Kemenparekraf (2019), Siaran Pers: Lombok Terpilih Sebagai Destinasi Wisata Halal Terbaik di Indonesia, diunduh 24 Juni, 2020, dari https://www.kemenparekraf.go.id/index.php/post/siaran-pers-lombok-terpilihsebagai-destinasi-wisata-halal-terbaik-di-indonesia

Kemenparekraf (2019), Siaran Pers: Lombok Terpilih Sebagai Destinasi Wisata Halal Terbaik di Indonesia, diunduh 24 Juni, 2020, dari https://www.kemenparekraf.go.id/index.php/post/siaran-pers-lombok-terpilihsebagai-destinasi-wisata-halal-terbaik-di-indonesia

Kusuma, U, A, Satria, D, Dan Manzilati, A._(2017). Modal Sosial Dan Ekowisata: Studi Kasus Di Bangsring Underwater, Kabupaten Banyuwangi. Jurnal Ilmu Ekonomi dan Pembangunan. 17 (2)

Leonard, M. (2005), "Children, childhood and social capital: Exploring the links", Sociology, 39 (4), 605-622.

Malhotra, N. K. (2014), Riset Pemasaran Pendekatan Terpadu, Jakarta: Indeks

jmm.unram.ac.id 
Miles, M.B, \& Huberman, A.M. (2009), Analisis Data Kualitatif. Terjemahan: Tjetjep Rohendi Rohidi, Jakarta: UI Press.

Moleong, L.J. (2018). Metodologi Penelitian Kualitatif, (Edisi revisi. Cetakan ketiga puluh delapan). Bandung : PT. Remaja Rosdakarya.

Morrow, V. (2003), "Conceptualizing social capital in relation to children and young people: Is it different for girls?" Paper presented at the Conference on "Gender and Social Capital", University of Manitoba, Winnipeg, Canada

Nisthar, S., \& Nufile, A.A.M. (2016), "Impacts of Multidiscplinary Teaching of Islam on Tourism: A Study of Islamic Religious Perspective". International Journal of Advanced Research and Review (IJARR), 1(7); 73-82.

Ntbprov.go.id (2019), Penetapan 99 desa wisata, diunduh 23 Juni 2020, dari https://www.ntbprov.go.id/post/tetapkan-99-desa-pemprov-awali-dengan-25desa-wisata

Pajriah, S. (2018), "Peran Sumber Daya Manusia dalam Pengembangan Pariwisata Budaya di Kabupaten Ciamis", Jurnal Artefak e-ISSN: 2580-0027

Peraturan Daerah Provinsi Nusa Tenggara Barat Nomor 2 Tahun 2016 Tentang Pariwisata Halal.

Pongponrat, J., \& Chantradoan, N.J. (2012), "Mechanism of Social Capital in Community Tourism Participator Planning in Samui Island, Thailand". An International Multidisciplinary Journal of Tourism, Volume 7, (1), 339-349.

Pramanik, P.D., Achmadi, M., \& Ingkadijaya, R. (2019), “The Role of Social Capital in Community Based Tourism, Journal of Indonesian Tourism and Development Studies, Vol.7, No.2, 63-73.

Putnam, R.D. (1995), “Bowling Alone: America's Declining Social Capital”, Journal of Democracy, 6 (1), 65-78.

Samori, Z., Salleh, N.Z.M., \& Khalid, M.M. (2016), "Current Trends in Halal Tourism: Case on selected Asian Countries", Tourism Management Perspectives, 19, 131-136.

Schenk, L., Sentse, M., Lenkens, M., Engbersen, G., de Mheen, D.V., Nagelhout, G.E., \& Severiens, S. (2018), "At-risk youths' self-sufficiency: The role of social capital and help-seeking orientation", Children and Youth Services Review, 91, 263-270.

Smylie, L. (2015), "The Nature and Development of Young People's Social Capital: Transitions, Co-Presence, Shared Interests, and Emotional Connections", International Journal of Child, Youth and Family Studies, 6(1): 134-149

Sukmayeti, E., \& Utami, V.Y. (2018), “Governansi Publik Model Co-Production oleh Aktor SocioPreneur (Kasus Desa Setanggor Dan Kawis Krisant)", Jurnal Ilmu Pemerintahan: Kajian Ilmu Pemerintahan dan Politik Daerah, Volume 3 - Nomor 2, 120-135.

Syahra, R. (2003), “Modal Sosial: Konsep dan Aplikasi”, Jurnal Masyarakt dan Budaya, Vol. 5 (1). 1-22.

Tiyasmono, D.K., Riyanti, G.A., \& Hardianto, F.N. (2019), “Model Konseptual Hubungan Modal Sosial dan Pengembangan Desa Wisata", proceeding Seminar Nasional dan Call for Papers 2019, Universitas Stikubank, Semarang 3 September 2019 Madic ISSN: 2443-2601.

Utami, V.Y. (2020), “Dinamika Modal Sosial dalam Pemberdayaan Masyarakat pada Desa Wisata Halal Setanggor: Kepercayaan, Jaringan Sosial dan Norma", Reformasi, Volume 10 Nomor 1, 34-44.

Weller, S. (2006), "Skateboarding alone? Making social capital discourse relevant to teenagers' lives", Journal of Youth Studies, 9 (5), 557-574.

Woolcock, M. (1998), "Social capital and economic development: Toward a theoretical synthesis and policy framework", Theory and Society, 27, 151-208. 
Zamani-Farahani, H., \& Musa, G. (2012) “The relationship between Islamic religiosity and residents' perceptions of socio-cultural impacts of tourism in Iran: Case studies of Sare'in and Masooleh", Tourism Management, 33, 802-814. 